\title{
Senior high school students' responses to graphical and mathematical representation items: The case of kinematics
}

\author{
Nur Utami Amaliah ${ }^{1 *}$, Alvi Hasanati ${ }^{2}$, Baiq Rizkia Ayu Latifa ${ }^{3}$, Sentot Kusairi ${ }^{4}$ \\ 1,2,3 Magister Program of Physics Education, Faculty of Mathematics \& Science, Universitas Negeri Malang, Indonesia \\ ${ }^{4}$ Department of Physics, Faculty of Mathematics \& Science, Universitas Negeri Malang, Indonesia
}

*Corresponding Address: utami.amaliah@gmail.com

\begin{tabular}{|c|c|}
\hline Article Info & \multirow{11}{*}{$\begin{array}{l}\text { This research aims to investigate and compare students' responses in solving } \\
\text { physics problems about kinematics concepts. The students' responses cover } \\
\text { the conceptual understanding as overall performance, representational } \\
\text { abilities, and students' response patterns. This research is a non-experimental } \\
\text { survey research with the quantitative-descriptive approach. The research } \\
\text { samples consisted of } 56 \text { students determined by the purposive sampling } \\
\text { technique. The research instrument was adapted from the Force Concept } \\
\text { Inventory (FCI) in Physport Assessment which has been validated. The } \\
\text { students' responses were analyzed using descriptive statistics to measure the } \\
\text { average and standard deviation. Students' answers were also grouped } \\
\text { according to the type of representation and pattern of presentation in } \\
\text { percentages. The results showed a significant difference between the tenth- } \\
\text { grade students' and eleventh-grade students' understanding of the Kinematics } \\
\text { concept. Furthermore, the students found it easier to answer mathematical } \\
\text { representation questions rather than graphical representation questions. }\end{array}$} \\
\hline Article history: & \\
\hline June 12, 2021 & \\
\hline Accepted: October 08, 2021 & \\
\hline Publis & \\
\hline Keywords: & \\
\hline Student Response; & \\
\hline Representation; & \\
\hline Mathematical; & \\
\hline Graphical; & \\
\hline & \\
\hline
\end{tabular}

(C) 2021 Physics Education Department, UIN Raden Intan Lampung, Indonesia.

\section{INTRODUCTION}

Kinematics is one of the fundamental concepts in physics. Thus students must understand it well (Sutopo et al., 2020). However, several studies show that many students continue to make mistakes in grasping this topic (Taqwa \& Rivaldo, 2018). The mistakes include the assumption that distance and displacement are the same (Jufriadi et al., 2021), unable to identify between speed and acceleration (Taqwa \& Rivaldo, 2018), two objects traveling the same distance having the same speed (Nadhor \& Taqwa, 2020).

Representation is one of the skills needed by students in learning physics. It helps students in mastering concepts well and solving physics problems (McPadden \& Brewe, 2017; Wulandari et al., 2019). Therefore, until now, students' representational skills have been considered an interesting topic to be discussed in physics studies, such as the concept of waves (Wiyantara et al., 2021), vector (Jewaru et al., 2021), kinematics (Phage et al., 2017), magnetic field (Fatmaryanti et al., 2017), free-body system (Poluakan \& Runtuwene, 2018), and force (Hamdani et al., 2019).

The common representation skills used when students solve problems are verbal, graphical, and mathematical representations. Some research has come up with the varied result of each type of representational problem. Lucas found that visual representation is better than other representations in solving problems (Lucas \& Lewis, 2019). In mathematical representation, the participants do not know about the physics' symbols interpretation. On the other hand, students possess high mathematical representation skills and low verbal representation skills (Puspitaningtyas et al., 2021). The same phenomenon was 
also encountered by Ekawati (Ekawati et al., 2019). She found that students had better mathematical representation skills and lacked verbal and graphical representations.

The multiple forms of representation are called multiple representations (Opfermann et al., 2017). It means representing a concept in different formats, such as verbal, pictorial, graphical, tables, diagrams, and mathematical equations (Bakri \& Muliyati, 2018). It also can assist students in learning and building their conceptions (Alami et al., 2018; Munfaridah et al., 2021), understanding physics concepts, and explaining them (Sianturi \& Abdurrahman, 2019).

Many studies use multiple representation problems as tools. Among them is research to measure students' higher-order thinking skills in the force concept (Puspitaningrum et al., 2021), using multiple representations to improve students' problem-solving skills (Setyarini et al., 2021), reveal students' multiple representation skills profile in heat material (Prahani et al., 2021), and analyze students' creative thinking (Ellianawati et al., 2020). Furthermore, Taher used it as a tool in learning activities to determine its effect on the mental model change (Taher et al., 2017) and improve conceptual understanding (Sutopo et al., 2020).

Research on multiple representations mostly uses multiple-choice items, such as the research by (Furqon \& Muslim, 2019) and (Rosa et al., 2018) with the two-tier items. These kinds of tests cannot express in-depth about students different performances or responses. Therefore, instead of using multiple-choice questions as in the original FCI, this research employed open-ended questions to allow students to express their responses using concepts they already knew, representations, and patterns in their own words. The items permitted students to come up with innovative solutions (Kaltakci Gurel et al., 2015).

Research that compares the ages or grades to determine the consistency of students' conceptual understanding is still rare. Previous research conducted by (Takaoğlu, 2018) compared the conceptual understanding of the $9^{\text {th }}$-grade, $10^{\text {th }}$-grade, and $11^{\text {th }}$-grade students on energy and other related concepts. Lin (Lin, 2017) used crossgrade to validate the students' mental models in the electrical circuit concept. Lastly, Abadan (Adadan \& Yavuzkaya, 2018) examined the progression and consistency of students' understanding of thermal concepts.

However, no studies have investigated students' responses to kinematics cases across ages or grades, particularly in Indonesia. Therefore, students from different grade levels were selected as participants in this research to compare the responses between those who had recently learned the concepts and those who had learned them after a long period. Therefore, this research informed instructors about students' responses in solving physics problems, especially in kinematics. This research focused on investigating the variations of students' concepts understanding, the differences of representations types used by students at every level, and the students' responses patterns when addressing the physics problems.

Based on the explanation, the overall goal of this research was to investigate and compare students' responses in solving physics problems, specifically in kinematic concepts. The students' responses were conceptual understanding as overall performance, representation skills, and students' responses patterns.

\section{METHODS}

This research was non-experimental research with the quantitative-descriptive approach. It determined the differences in students' understanding based on the representation of graphical and mathematical problems. The research steps can be seen in Figure 1. 


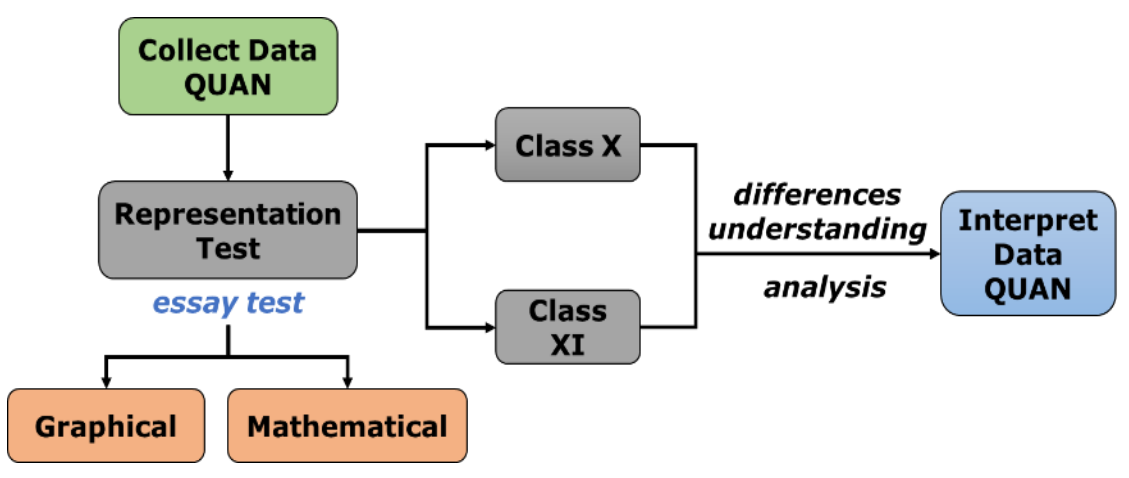

Figure 1. Research Flowchart

The sampling technique used in this research was purposive sampling. The research subjects were 56 students, consisting of 31 tenth-grade students and 25 eleventh-grade students. The students came from one of the state senior high schools in Palu with an age range of 15 to 17 years old. The students had studied the kinematics learning materials. The subjects were selected from different grades to compare the conceptual understanding of those who have just learned the concept and those who have learned it after quite a long time. Both classes were taught by the same teacher and have mastered the concept.

The researchers collected the data using representation tests. The items consisted of graphical and mathematical representations. The test was composed of four description questions presented in the form of graphical and mathematical representations. Experts had validated the representation test questions. The questions were adapted from Force Concept Inventory (FCI) questions number 19 and 20, generally in the form of multiple-choice questions. The other two questions were the modification results of the questions from graphical to mathematical format.

The problems adapted from FCI focused on the velocity and acceleration in the straight motion. The learning materials were just finished being discussed in physics class (in the tenth grade). The research revealed that most students had difficulty applying the concepts to solve kinematics problems presented in the non-mathematical representation (Sutopo et al., 2020). Therefore, this research chose these two questions to be the instruments because they contained graphical representations.

Students' answers were analyzed with descriptive statistics approach to determine the mean score and standard deviation. The results were grouped by type of representation and pattern of answers in each item. The analysis was displayed in the form of percentages. The items used in this research are presented in Table 1.

Table 1. Description of Instruments Used in the Research

\begin{tabular}{|c|c|c|c|}
\hline $\begin{array}{c}\text { Kinematics } \\
\text { Concepts }\end{array}$ & $\begin{array}{c}\text { Item } \\
\text { Number }\end{array}$ & Representation & Description \\
\hline \multirow[t]{2}{*}{ Velocity } & 1 & Graphical & $\begin{array}{l}\text { The students were given a graph of the displacement of two blocks' } \\
\text { positions. Then, they were asked to indicate and explain the position } \\
\text { of the two blocks with the same speed. }\end{array}$ \\
\hline & 2 & Mathematical & $\begin{array}{l}\text { The students were given two equations of the position of objects. } \\
\text { Then, they were asked to prove and explain which block moves } \\
\text { constantly. }\end{array}$ \\
\hline \multirow[t]{2}{*}{ Acceleration } & 3 & Graphical & $\begin{array}{l}\text { The students were given a graph of the displacement of two blocks' } \\
\text { positions. Then, they were asked to show and explain the motion of } \\
\text { the two blocks in terms of acceleration. }\end{array}$ \\
\hline & 4 & Mathematical & $\begin{array}{l}\text { The students were given two equations of the position of objects. } \\
\text { Then, they were asked to prove and explain if the two blocks had the } \\
\text { same acceleration. }\end{array}$ \\
\hline
\end{tabular}


RESULTS AND DISCUSSION

Conceptual Understanding Based on Students' Overall Performance

This section shows the students' overall performances. The descriptive statistics analysis showed that the mean score of the tenth-grade students' concept understanding was 27.82, and the mean score of the eleventh-grade students' concept understanding was 55.25. In general, the eleventh-grade students' concept understanding was better than the tenthgrade students. Table 2 shows the results of the descriptive statistics.

Table 2. Descriptive Statistics

\begin{tabular}{ccc}
\hline \multirow{2}{*}{ Variable } & \multicolumn{2}{c}{ Score } \\
\cline { 2 - 3 } & $\begin{array}{c}\text { Tenth- } \\
\text { grade }\end{array}$ & $\begin{array}{c}\text { Eleventh- } \\
\text { grade }\end{array}$ \\
\hline Total Students & 31 & 25 \\
\hline Standard Deviation & 22.53 & 23.08 \\
\hline Minimum Score & 0.00 & 25.00 \\
\hline Maximum Score & 75.00 & 93.75 \\
\hline Average & 27.82 & 55.25 \\
\hline
\end{tabular}

The results were obtained to determine the differences in students' conceptual understanding regarding the type of problem representation.

\section{The differences of Students' Conceptual Understanding in Terms of the Representations Types}

In item number 1 , the eleventh-grade students had a lower score percentage of about $10 \%$. The data were obtained by grouping students' correct answers and calculating the average percentage on item number 1 and 3 for graphic representation, and item number 2 and 4 for mathematical representation. The data shows that the score percentage of the tenth-grade students who can answer the graphical representation questions was $27.42 \%$ and the score percentage of the eleventh-grade students was $42 \%$. Furthermore, the tenth-grade students' mathematical representation percentage was $31.88 \%$, and the eleventhgrade students' mathematical representation percentage was $86 \%$. The data indicated that both classes answered mathematical representations questions correctly compared to the graphical representations questions. The students' answers reviewed based on the item questions are presented in Figure 2.

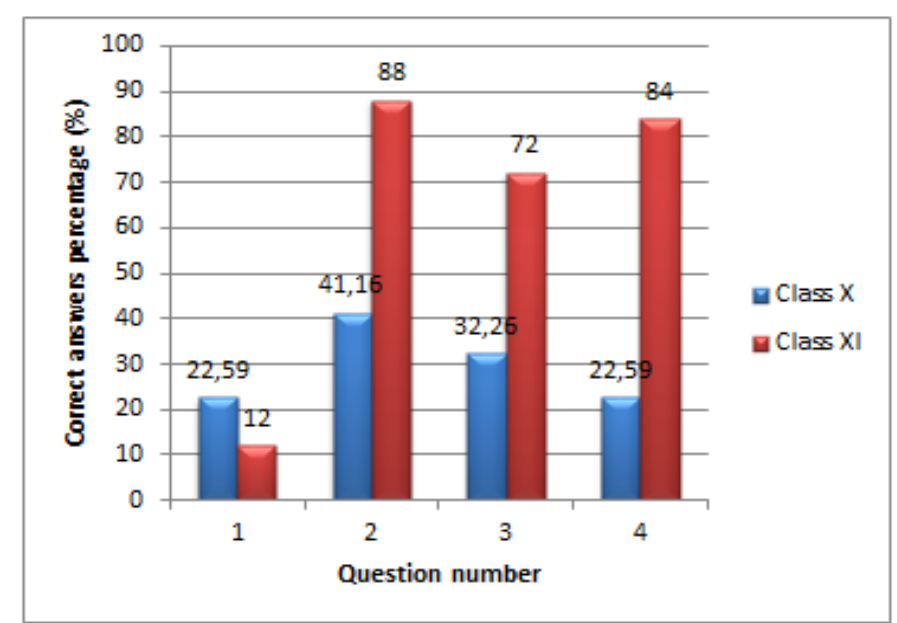

Figure 2. The Percentages of Students' Correct Answers for each Question

The answer patterns presented in Figure 2 are a general description of how students solve problems related to kinematics concepts with different problem representations.
Students' Conceptual Understanding Based on the Pattern of Generated Answers

Figure 2 shows that in item number 1, the eleventh-grade students answered more questions than tenth-grade students. 
However, viewed from the generated pattern, the tenth-grade students answered less correctly. The students answered verbally by reviewing the movement of the blocks, then described it as speed. Figure 3 presents an example of a student's answer.

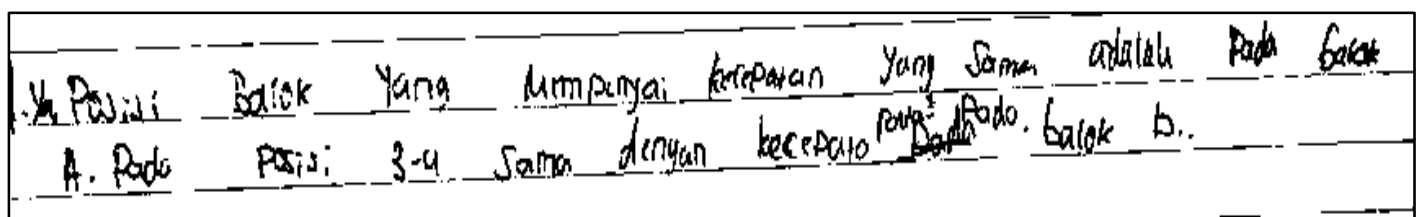

Figure 3. Student Answer for Pattern 2 on Item Number 1

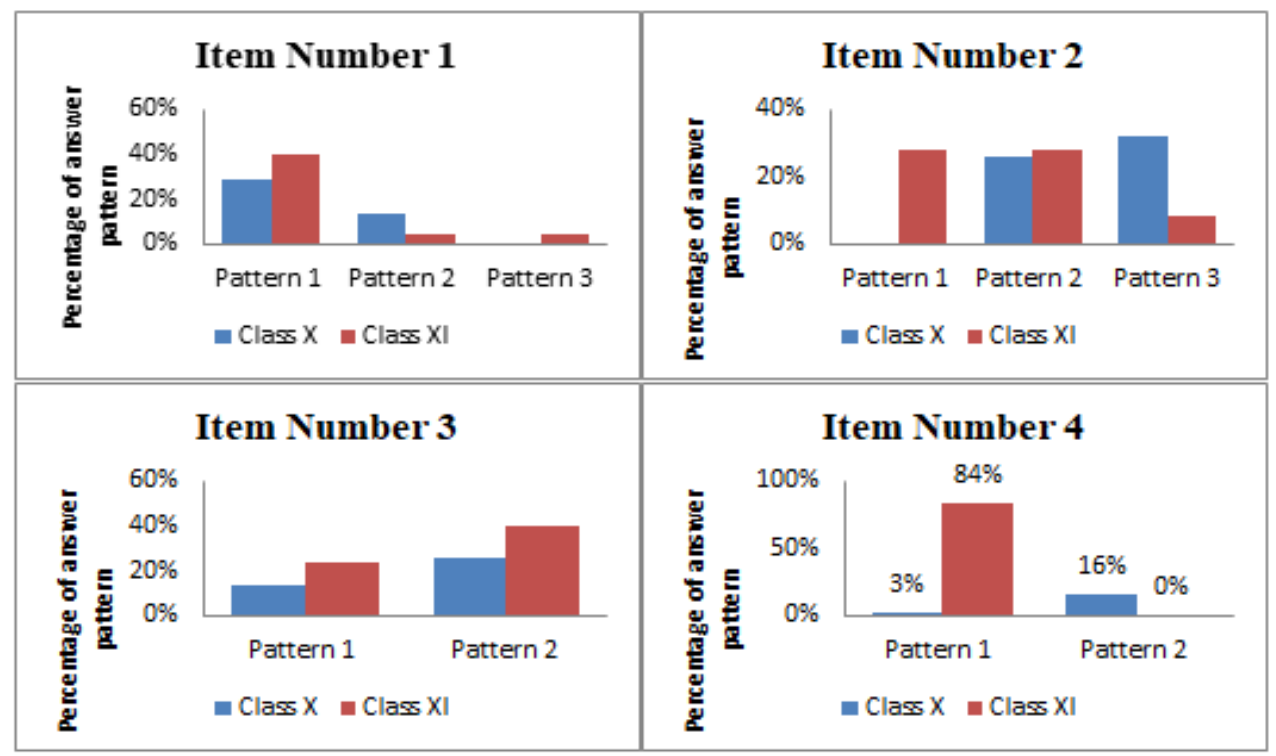

Figure 4. The Percentages of Students' Answer Patterns for Each Item

Item number 2 shows that the eleventhgrade students answered better than the tenth-grade students who could not answer the questions at all. If viewed from the generated pattern, the students in both grades had an answer pattern with approximately the same percentage in answer pattern 2. The description was,
"Students answer mathematically by entering the value of $t=1$ to $t=4$ in the given equation." In the problem, block B had a constant velocity through the change in the position of the obtained block. The example of a student's response is displayed in Figure 5.

$\begin{array}{rlrlr}x=\frac{1}{2} t^{2}+\frac{1}{2} t+1 & (2) x=\frac{1}{2}(2)^{2}+\frac{1}{2}(2)+1 & (3) x: \frac{1}{2}(5)^{2}+\frac{1}{2}(3)+1 & (4) x=\frac{1}{2}(9)^{2}+\frac{1}{2}(4)+1 \\ =\frac{1}{2}(1)^{2}+\frac{1}{2}(1)+1 & =\frac{1}{2} 4+\frac{2}{2}+1 & =\frac{1}{2}(9)+\frac{3}{2}+1 & =\frac{1}{2}(16)+2+1 \\ =\frac{1}{2}+\frac{1}{2}+1 & =2+1+1 & =\frac{9}{2}+\frac{3}{2}+1 & =8+2+1 \\ =2 & =4 & =6+1 & =11 \\ & = & & =7\end{array}$

Balok 8 . Karend $t(1-4)$ kecepaton ronitan yaity $0,4,8,12$

Figure 5. A Student's responses for Pattern 2 on Item Number 2 
Item number 3 shows that the eleventhgrade students could answer more questions than the tenth-grade students. The percentage of answers for each pattern was almost the same. The error in answering question number 3 was in pattern 2 , namely, "Students answer the question by assuming that the speed and acceleration are the same and constant." The example of a student's response is displayed in Figure 6.

\begin{tabular}{|c|c|c|c|c|c|c|c|}
\hline \multirow{2}{*}{$\begin{array}{l}\text { Barok } \\
\text { Perbedaan }\end{array}$} & \multicolumn{2}{|c|}{ mam ponyal } & \multicolumn{2}{|c|}{ kecepatan } & Jeontan & tarina & \multirow{2}{*}{$\frac{\operatorname{memf} u k i}{\operatorname{bov}(x) B}$} \\
\hline & $4 \mathrm{~m} / \mathrm{s}$ & & ontara & baiok & aloknya. & Beyifopuia & \\
\hline mermistas & Derbedaan & 6 & $\mathrm{~m}_{\mathrm{f}}$ & Karena & kezupatan & bonok & $B \operatorname{dan} B$ \\
\hline Konston, & maka & ans & paya & Icon & Q & & \\
\hline
\end{tabular}

Figure 6. Student Responses for Pattern 2 on Item Number 3

Item number 4 shows that almost all eleventh-grade students could answer the question correctly because of their experiences. It was very different from the tenth-grade students who answered only partially. The tenth-grade students had more answer patterns: "Students enter the value of $t$ into the equation given in the problem, then conclude that the velocity and acceleration of the two blocks are constant." The example of a student's response is displayed in Figure 7.

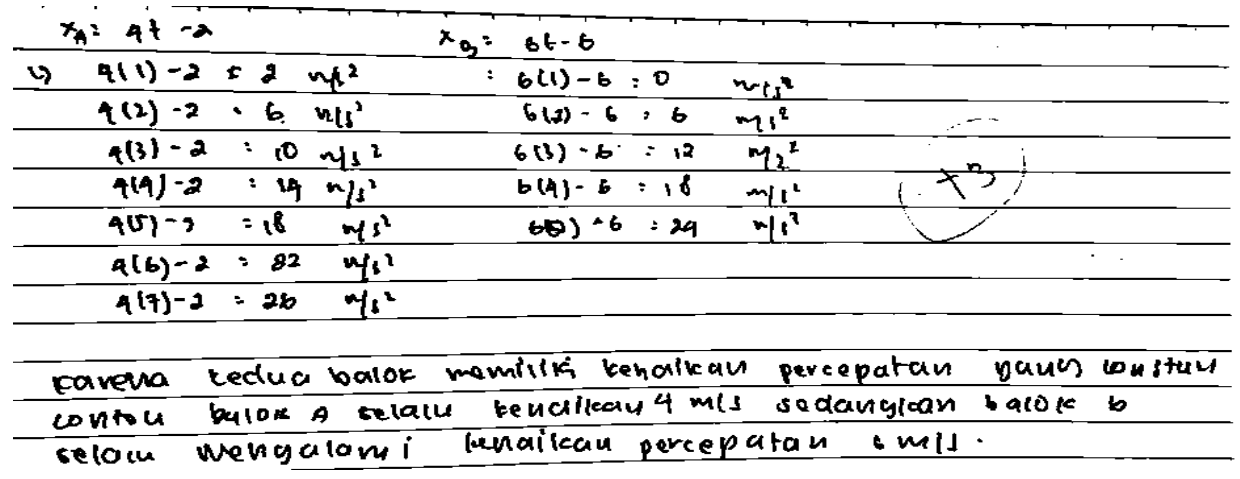

Figure 7. A Student's Response for Pattern 2 on Item Number 4

Based on the average number of correct answers, the percentage of the eleventhgrade students was higher than the tenthgrade students. The eleventh-grade students were better at solving physics problems in the form of graphical and mathematical representation because the difference in grade levels significantly affects one's understanding. Lin (2017) states that students in higher grades have more experience with physics concepts to master the concept better. She also states that different grades can affect the results because higher grades will improve reasoning and the ability to solve physics problems. Higher grades have some factors to influence their concept understanding, namely the time of studies, intensive resources, and problems validation (Driver et al., 1994). More studies can develop conceptual knowledge (Stevens et al., 2009) because they have more experience and experiments (Tural, 2015).

It was easier for students to answer mathematical representation questions than graphical representations based on the data analysis. Students studying physics often use books in which there are many mathematical questions. Therefore, the students have not mastered questions in different contexts. Previous research reveals that students possess good mathematical representation abilities (Ekawati et al., 2019; Puspitaningtyas et al., 2021) because 
physics learning in the classroom tends to apply mathematical concepts. Therefore, the students are more familiar with mathematical problems.

Based on the discussion about the pattern of students' answers, several interesting things were found. The first is that students find it difficult to analyze the motion of objects if the questions are presented in graphical representations. The second is the lack of understanding in using the concepts of position, velocity, and acceleration. The third is learning resources in schools that are widely used today, especially in kinematics material, discuss many problems using mathematical representations.

The benefit of this research is to provide information to the teacher that students answer better in mathematical representations rather than graphical representations. Furthermore, students who have more experience in solving physics problems can master these concepts better. This research can also be used as a reference for further researchers to understand kinematics concepts for the tenth-grade and the eleventh-grade students' by using these two representations. Thus, instructors may take these findings into consideration for developing learning models that will be used in the classroom to assist students in better understanding concepts and improve their multi-representation abilities in physics.

It is recommended that the teacher should explain the movement position changes in other forms of representation, such as graphical and mathematical representations. Furthermore, in the kinematics concept, it is necessary to explain that constantly does not mean zero since many researchers see from the student answers that constant is identical to zero. The researchers recommend that some concrete examples should be given to illustrate abstract physics concepts in understanding the concept of kinematics. Therefore, students can understand more quickly. The shortcomings in the study are the lack of existing participants and the variety of levels or grades of students. Further research should pay attention to these matters.

\section{CONCLUSION AND SUGGESTION}

Based on the results and discussion, the eleventh-grade students understand concepts better than the tenth-grade students. Furthermore, the students answer questions correctly on mathematical representation items rather than graphical representations. In terms of students' concepts understanding, the students had difficulty analyzing the motion of objects in the form of graphic representations. Besides, the students did not understand the concept of kinematics and changes in the equations of position, velocity, and acceleration. Therefore, it is recommended for physics teachers to provide students with other representations to be more meaningful and easier to understand. Another suggestion for further researchers is to add samples to present more specific data.

\section{ACKNOWLEDGMENT}

The researchers would like to thank the supervisors for their guidance and direction. The researchers also express their gratitude to the principal and physics teacher at SMA Palu, Mrs. Sofwiyatul Banat, S.Pd, for the assistance in carrying out this research.

\section{REFERENCES}

Adadan, E., \& Yavuzkaya, M. N. (2018). Examining the progression and consistency of thermal concepts: A cross-age study. International Journal of Science Education, 40(4), 371-396.

https://doi.org/10.1080/09500693.20 18.1423711

Alami, Y., Sinaga, P., \& Setiawan, A. (2018). The problem solving skills and student generated representations (SGRs) profile of senior high school students in Bandung on the topic of work and energy. Journal of Physics: 
Conference Series, 1013, 012036. https://doi.org/10.1088/17426596/1013/1/012036

Bakri, F., \& Muliyati, D. (2018). Design of multiple representations e-learning resources based on a contextual approach for the basic physics course. Journal of Physics: Conference Series, 1013, 012037. https://doi.org/10.1088/17426596/1013/1/012037

Driver, R., Leach, J., Scott, P., \& WoodRobinson, C. (1994). Young People's understanding of science concepts: Implications of cross-age studies for curriculum planning. Studies in Science Education, 24(1), 75-100. https://doi.org/10.1080/03057269408 560040

Ekawati, R., Setiawan, A., Wulan, A. R., \& Rusdiana, D. (2019). The use of classroom assessment based on multi-representation ability in Mechanics concept. Journal of Physics: Conference Series, 1157, 032061. https://doi.org/10.1088/17426596/1157/3/032061

Ellianawati, Mufiatunnikmah, S., Setyaningsih, N. E., \& Subali, B. (2020). Profile of creative thinking abilities of students measured by multi representation-based creative thinking assessment. Journal of Physics: Conference Series, 1567, 022047.

https://doi.org/10.1088/1742-

6596/1567/2/022047

Fatmaryanti, S. D., Suparmi, Sarwanto, \& Ashadi. (2017). Student representation of magnetic field concepts in learning by guided inquiry. Journal of Physics: Conference Series, 795, 012059. https://doi.org/10.1088/17426596/795/1/012059

Furqon, M., \& Muslim. (2019). Investigating the ability of multiple representations and scientific consistency of high school students on newton's laws. Journal of Physics: Conference Series, 1280, 052041.

https://doi.org/10.1088/17426596/1280/5/052041

Hamdani, H., Mursyid, S., \& Sirait, J. (2019). Using physics representation worksheet to enhance students' understanding and performance about force. Journal of Physics: Conference Series, 1157, 032013. https://doi.org/10.1088/17426596/1157/3/032013

Jewaru, A. A. L., Umrotul, Kusairi, S., \& Pramono, N. A. (2021). Senior high school students understanding of vector concepts in mathematical and physical representations. 050024. https://doi.org/10.1063/5.0043433

Jufriadi, A., Kusairi, S., \& Sutopo, S. (2021). Exploration of student's understanding of distance and displacement concept. Journal of Physics: Conference Series, 1869(1), 012195.

https://doi.org/10.1088/17426596/1869/1/012195

Kaltakci Gurel, D., Eryilmaz, A., \& McDermott, L. C. (2015). A review and comparison of diagnostic instruments to identify students' misconceptions in Science. EURASIA Journal of Mathematics, Science and Technology Education, $11(5)$.

https://doi.org/10.12973/eurasia.201 5.1369a

Lin, J.-W. (2017). A cross-grade study validating the evolutionary pathway of student mental models in electric circuits. EURASIA Journal of Mathematics, Science and Technology Education, 13(7). https://doi.org/10.12973/eurasia.201 7.00707a

Lucas, L. L., \& Lewis, E. B. (2019). High school students' use of 
representations in physics problem solving. School Science and Mathematics, 119(6), 327-339. https://doi.org/10.1111/ssm.12357

McPadden, D., \& Brewe, E. (2017). Impact of the second semester university modeling instruction course on students' representation choices. Physical Review Physics Education Research, 13(2), 020129. https://doi.org/10.1103/PhysRevPhy sEducRes.13.020129

Munfaridah, N., Avraamidou, L., \& Goedhart, M. (2021). The Use of multiple representations in undergraduate physics education: What do we know and where do we go from here? Eurasia Journal of Mathematics, Science and Technology Education, 17(1), em1934. https://doi.org/10.29333/ejmste/9577

Nadhor, N., \& Taqwa, M. R. A. (2020). Pemahaman konsep kinematika mahasiswa calon guru fisika: Ditinjau dari level pemahaman dan teori resource. PENDIPA Journal of Science Education, 4(3), 82-90. https://doi.org/10.33369/pendipa.4.3. 82-90

Opfermann, M., Schmeck, A., \& Fischer, H. E. (2017). Multiple representations in physics and science education why should we use them? In D. F. Treagust, R. Duit, \& H. E. Fischer (Eds.), Multiple Representations in Physics Education, 10(1), 1-22. Springer International Publishing. https://doi.org/10.1007/978-3-31958914-5_1

Phage, I. B., Lemmer, M., \& Hitge, M. (2017). Probing factors influencing students' graph comprehension regarding four operations in kinematics graphs. African Journal of Research in Mathematics, Science and Technology Education, 21(2), 200-210. https://doi.org/10.1080/18117295.20 17.1333751

Poluakan, C., \& Runtuwene, J. (2018). Students' difficulties regarding vector representations in free-body system. Journal of Physics: Conference Series, 1120, 012062. https://doi.org/10.1088/17426596/1120/1/012062

Prahani, B. K., Deta, U. A., Lestari, N. A., Yantidewi, M., RJauhariyah, M. N., Kelelufna, V. P., Siswanto, J., Misbah, M., Mahtari, S., \& Suyidno, S. (2021). A profile of physics multiple representation ability of senior high school students on heat material. Journal of Physics: Conference Series, 1760, 012020. https://doi.org/10.1088/17426596/1760/1/012020

Puspitaningrum, H. Z., Wasis, \& Prastowo, T. (2021). High order thinking skills students through multirepresentation test on newtons law study. Journal of Physics: Conference Series, 1805(1), 012010. https://doi.org/10.1088/17426596/1805/1/012010

Puspitaningtyas, E., Hasanah, S., Kusairi, S., \& Purwaningsih, E. (2021). Physics students' responses when asked to select and solve motion kinematics problems in various representations. AIP Conference Proceedings, 2330(1), 1-6.

https://doi.org/10.1063/5.0043437

Rosa, G. C., Cari, C., Aminah, N. S., \& Nugraha, D. A. (2018). Students' conception and multiple representations skill on rigid body collision, AIP Conference Proceedings, 2014(1), 1-10. https://doi.org/10.1063/1.5054457

Setyarini, D. A., Imam Supardi, Z. A., \& Elok Sudibyo. (2021). Improving senior high school students' physics problem-solving skills through investigated based multiple representation (IBMR) learning 
model. IJORER: International Journal of Recent Educational Research, 2(1), 42-53. https://doi.org/10.46245/ijorer.v2i1.7 4

Sianturi, I. N., \& Abdurrahman. (2019). Exploring multiple representation preference to develop students misconception inventory in measuring of students science conception awareness. Journal of Physics: Conference Series, 1233, 012039.

https://doi.org/10.1088/17426596/1233/1/012039

Stevens, S. Y., Delgado, C., \& Krajcik, J. S. (2009). Developing a hypothetical multi-dimensional learning progression for the nature of matter. Journal of Research in Science Teaching, 47(6), 687-715. https://doi.org/10.1002/tea.20324

Sutopo, Hidayah, N., Wisodo, H., \& Haryoto, D. (2020). Improving students' understanding of kinematics concepts through multirepresentational learning, AIP Conference Proceedings 2215 030026. https://doi.org/10.1063/5.0004063

Taher, M., Hamidah, I., \& Suwarma, I. R. (2017). Profile of students' mental model change on law concepts archimedes as impact of multirepresentation approach. Journal of Physics: Conference Series, 895, 012101. https://doi.org/10.1088/17426596/895/1/012101

Takaoğlu, Z. B. (2018). Energy concept understanding of high school students: a cross-grade study. Universal Journal of Educational Research, 6(4), 653-660. https://doi.org/10.13189/ujer.2018.0 60409

Taqwa, M. R. A., \& Rivaldo, L. (2018). Kinematics conceptual understanding: interpretation ofposition equations as a function of time. Jurnal Pendidikan Sains, 6(4), 120-127.

Tural, G. (2015). Cross-grade comparison of students' conceptual understanding with lenses in geometric optics. Science Education International, 26((3)), 325-343.

Wiyantara, A., Widodo, A., \& Prima, E. C. (2021). Identify students' conception and level of representations using five-tier test on wave concepts. Journal of Physics: Conference Series, $\quad 1806(1), \quad 012137$. https://doi.org/10.1088/17426596/1806/1/012137

Wulandari, Hariadi, M. H., Jumadi, Wilujeng, I., \& Kuswanto, H. (2019). Improving mathematical representation ability of student's senior high school by inquiry training model with google classroom. Journal of Physics: Conference Series, 1233, 012043. https://doi.org/10.1088/17426596/1233/1/012043 